\title{
UJI KARAKTERISTIK FISIK DAN KIMIA PAKAN LOKAL DAN IMPOR KUDA PACU MINAHASA
}

\author{
Veity .M. Pongoh*, B. Tulung**, Y.L.R. Tulung**, L.J.M Rumokoy** \\ Fakultas Peternakan, Universitas Sam Ratulangi, 95115
}

\begin{abstract}
ABSTRAK
Penelitian ini dilakukan untuk mengetahui karakteristik fisik dan kandungan nilai nutrisi pakan kuda pacu baik pakan lokal maupun impor yang sering digunakan peternak di Minahasa. Manajemen pemeliharaan kuda pacu di Indonesia sebagian besar masih mengacu pada pemberian pakan yang dilakukan oleh negara maju di luar negeri. Kebiasaan para peternak di minahasa saat ini, masih menggunakan pakan impor oat untuk mengganti pakan lokal padi. Hal ini disebabkan belum adanya pengujian lebih lanjut dari pakan lokal, sehingga masyarakat peternak kuda pacu memelihara kuda tersebut masih secara turun-temurun dengan mengandalkan bahan baku pakan impor yang digunakan menjelang perlombaan. Penelitian ini menggunakan metode survei. Teknik pengambilan data adalah wawancara dan pengamatan langsung pada lokasi-lokasi peternakan kuda pacu. Data yang dikumpulkan yakni jenis dan jumlah pakan (hijauan dan konsentrat) baik lokal maupun impor yang diberikan pada ternak kuda pacu, masingmasing diambil sampel 500gr. Data hasil penelitian dianalisis statistik dengan menggunakan uji $t$ ( $t$ test). Hasil uji t, menunjukan bahwa kandungan nilai nutrisi pakan impor berbeda nyata lebih tinggi $(\mathrm{P}<0,05)$ dibandingkan dengan pakan lokal. Berdasarkan hasil uji t, menunjukkan bahwa karakteristik fisik (warna, aroma, bentuk, tekstur) pakan lokal (padi) berbeda nyata $(\mathrm{P}<0,05)$ dengan pakan impor (oat). Berdasarkan hasil penelitian ini dapat disimpulkan bahwa kandungan nilai nutrisi pakan impor lebih tinggi dibandingkan dengan pakan lokal, dan berdasarkan hasil pengujian karakteristik fisik yang telah dilakukan pada struktur dan sifat fisik oat dan padi terdapat
\end{abstract}

*Alumni Fakultas Peternakan

**Jurusan Nutrisi dan Makanan Ternak perbedaan warna, bentuk, aroma, tekstur namun jika dilihat sekilas, oat dan padi memiliki bentuk fisik yang sama.

\author{
Kata kunci: karakteristik Fisik, Kimia, \\ Kuda Pacu, Pakan Lokal, \\ Pakan Impor.
}

\section{ABSTRACT}

PHYSICAL AND CHEMICAL CHARACTERISTICS APPRAISAL OF LOCAL AND IMPORTED RACE HORSES FEED IN MINAHASA The present study was conducted to determine the physical characteristics and nutrient content of racehorse diets both local and imported feed used mostly by race horse breeders in Minahasa region. Race horse breeding management in Indonesia fully adopts methods used in developed countries. Race horse breeders in Minahasa have been practicing of using oats as an imported ingredient to replace local feed rice. This is due to the lack of further testing of local feed, so that race horse breeders practice and rely on using imported feed ingredients to feed their horses just before the horse racing. A survey method was used to collect data, using interviews and direct observations on several race horses breeding farms. Types and amount of feed (forage and concentrates) both local and imported given to race horse were taken about 500gr for samples analysis. Data were statistically analyzed using t-test. The results showed that the nutrient content of imported feed ingredients significantly higher $(\mathrm{P}<0.05)$ compared with local feed. Physical characteristics (color, flavour, shape, and texture) of local food (rice) was significantly different $(\mathrm{P}<0.05)$ from that of imported feed (oats). It can be concluded that the nutrient content of imports feed is higher than that of 
local feed, and physical characteristics of oat and rice, different in colour, shape, aroma, and texture, on the other hand, oat and rice have the same physical shape.

\section{Keywords: Physical characteristics, Chemistry, Race horse, Local Feed, Imported Feed.}

\section{PENDAHULUAN}

Tujuan produksi ternak kuda yang dikenal selama ini salah satunya adalah untuk kemampuan kerja yaitu sebagai kuda pacu (Blackely dan Bade, 1991). Kuda pacu sebagai ternak untuk perlombaan mempunyai keunikan dalam hal mengkonsumsi pakan. Salah satu tujuan pemberian pakan untuk kuda pacu yaitu agar memperoleh prestasi atau juara pada saat pacuan atau perlombaan, oleh sebab itu perlu diperhatikan kebutuhan pakan maupun zat-zat makanan yang terkandung dalam pakan, terlebih kandungan energi yang mempunyai peran utama pada saat kuda dipacu. Kecernaan zat-zat makanan merupakan faktor yang sangat menentukan kualitas bahan pakan yang dikonsumsi ternak kuda, karena tinggi rendahnya kecernaan bahan pakan memberikan arti seberapa besar bahan pakan itu memiliki sifat fisik yang baik serta mengandung zat-zat makanan dalam bentuk yang dapat dicernakan ke dalam saluran pencernaan.
Beberapa tahun terakhir ini terjadi penurunan populasi kuda pacu di Sulawesi Utara, padahal Sulawesi Utara khususnya Minahasa merupakan lokasi pemeliharaan kuda pacu yang memiliki potensi yang cukup besar untuk pengembangan ternak kuda pacu. Hal ini disebabkan karena harga pakan yang terlalu mahal, sehingga minat masyarakat petani peternak kuda pacu menurun, dan yang bertahan untuk memelihara kuda pacu tinggal orang-orang yang mempunyai banyak modal.

Manajemen pemeliharaan kuda pacu di Indonesia umumnya masih mengacu pada pemberian pakan yang dilakukan oleh negara maju di luar negeri dan masih memberikan pakan impor sebagai pakan utama menjelang pacuan. Bahan baku pakan lokal menurut hasil-hasil analisis kandungan zat-zat makanan tidak kalah dibandingkan dengan komposisi zat-zat makanan dari negara luar. Apabila dilihat dari hasil yang diperoleh pada saat pacuan, ternyata penggunaan pakan lokal tidak kalah dibandingkan dengan kuda yang menggunakan pakan impor (Tulung, 2012). Gabah merupakan pakan lokal yang sering diganti dengan pakan impor oat pada saat menjelang pacuan. Jika dilihat sekilas gabah dan oat memiliki karakteristik fisik yang sama, namun belum ada pengujian karakteristik fisik 
yang lebih lanjut untuk perbedaan gabah dan oat. Namun pakan impor yang dikonsumsi kuda pacu Minahasa mengandung nilai kecernaan yang nyata lebih tinggi dibandingkan dengan pakan lokal. Hal ini mungkin disebabkan karena kualitas (sifat fisik) dari pakan impor masih lebih baik dari pakan lokal (Tulung, 2012). Oleh karena itu perlu dilakukan penelitian untuk melihat perbedaan karakteristik fisik gabah dan oat serta kandungan nutrisi dan energi pakan lokal dan impor kuda pacu minahasa.

\section{MATERI DAN METODE PENELITIAN}

Penelitian ini telah dilaksanakan di desa Tompaso II, Kecamatan Tompaso, Kabupaten Minahasa selama 10 hari terhitung mulai tanggal 27 Oktober sampai dengan tanggal 5 November 2013. Pakan yang digunakan adalah rumput Australia (Brachiaria mutica), rumput paspalum sp, tebon jagung, dan pakan konsentrat yang terdiri dari pakan lokal dan import antara lain; jagung (Zea mays L), kacang hijau, gabah (oriza sativa), kedelai (Glycine max), Oat (Avesia sativa), sustaina.

Data yang dikumpulkan yakni jenis dan jumlah pakan (hijauan dan konsentrat) yang diberikan pada ternak kuda pacu yang diambil masing-masing 500gr untuk pakan lokal dan impor yang akan dianalisis kandungan nilai nutrisinya serta 200gr untuk oat dan gabah yang akan dibandingkan karakteristiknya menggunakan mikroskop.

Tabel 1. Uji Karakteristik Fisik Pakan

\begin{tabular}{|c|c|c|c|}
\hline \multirow{2}{*}{ KRITERIA } & \multicolumn{2}{|c|}{ KARAKTERISTIK } & \multirow{2}{*}{ SKOR } \\
\hline & GABAH & OAT & \\
\hline BENTUK & $\begin{array}{l}\text { RAMPING PENDEK } \\
\text { RAMPING MEMANJANG } \\
\text { GEMUK MEMANJANG }\end{array}$ & $\begin{array}{l}\text { RAMPING MEMANJANG } \\
\text { PENDEK GEMUK } \\
\text { GEMUK MEMANJANG }\end{array}$ & $\begin{array}{l}1-3 \\
4-6 \\
7-9\end{array}$ \\
\hline WARNA & $\begin{array}{l}\text { KECOKLATAN } \\
\text { KUNING KECOKLATAN } \\
\text { KUNING KOTOR }\end{array}$ & $\begin{array}{l}\text { KUNING KOTOR } \\
\text { KUNING KECOKLATAN } \\
\text { KUNING BERSIH }\end{array}$ & $\begin{array}{l}1-3 \\
4-6 \\
7-9\end{array}$ \\
\hline AROMA & $\begin{array}{l}\text { BAU TENGIK } \\
\text { TIDAK ADA BAU } \\
\text { WANGI (AROMA KHAS PADI) }\end{array}$ & $\begin{array}{l}\text { BAU TENGIK } \\
\text { TIDAK ADA BAU } \\
\text { WANGI (AROMA KHAS OATS) }\end{array}$ & $\begin{array}{l}1-3 \\
4-6 \\
7-9\end{array}$ \\
\hline TEKSTUR & $\begin{array}{l}\text { TIDAK BERAMBUT } \\
\text { KURANG BERAMBUT } \\
\text { BERAMBUT }\end{array}$ & $\begin{array}{l}\text { KASAR } \\
\text { LICIN } \\
\text { SEDIKIT BERAMBUT }\end{array}$ & $\begin{array}{l}1-3 \\
4-6 \\
7-9\end{array}$ \\
\hline
\end{tabular}

Sumber: McEllhlary. R. R. 1994. 
Penelitian ini menggunakan metode survei. Teknik pengambilan data adalah wawancara dan pengamatan langsung pada lokasi-lokasi peternakan kuda pacu. Uji karakteristik fisik hanya membandingkan pakan lokal gabah dan pakan impor oat, karna para peternak di Minahasa mengganti gabah dengan oat pada saat menjelang perlombaan. Data untuk perbandingan karakteristik fisik menggunakan tabel skor terhadap warna, bau, aroma, tekstur (tabel 1). Data hasil penelitian dianalisis dengan menggunakan uji t (t test).

\section{Tatalaksana Penelitian}

1. Tahap Pendahuluan :

Survei dan pengamatan langsung di lokasi peternakan kuda pacu. Dilakukan pengumpulan data atau informasi dari peternak/pemilik ternak kuda dengan wawancara secara langsung di lokasi peternakan kuda pacu.

2. Tahap Pra-Koleksi :

7 (tujuh) hari sebelum pengambilan data, dilakukan pengamatan pemberian pakan untuk memastikan jenis dan jumlah pakan yang diberikan untuk kuda pacu oleh para pekerja.

3. Tahap Koleksi :
Pengumpulan dan pengambilan sampel pakan dilakukan selama 1 hari

\section{Analisis Sampel}

Untuk analisis kandungan nilai nutrisi, sampel pakan lokal maupun impor dibawa ke Laboratorium Baristand Industri Manado untuk dianalisis masing-masing kandungan energi dan nutrisinya.

Analisis karakteristik fisik oat dan gabah dilakukan di Laboratorium Fakultas Peternakan UNSRAT dengan menggunakan tabel skor yang akan diisi oleh 10 orang (yang terdiri dari para dosen dan mahasiswa).

\section{Variable yang diamati}

1. Bentuk fisik pakan

- Bentuk

- Warna

- Aroma

- Tekstur

2. Kandungan nutrisi dan energy

\section{HASIL DAN PEMBAHASAN}

Data diperoleh dari beberapa peternakan kuda pacu yang memberikan konsumsi pakan lokal maupun pakan impor. Pakan-pakan lokal yang biasanya digunakan adalah jagung, gabah, kedele, kacang hijau, rumput letup, rumput Australia, tebon jagung dan pakan impor 
yang biasanya digunakan adalah oat dan sustena.

\section{Uji Karakteristik Fisik Gabah dan Oat}

Hasil pengamatan melalui mikroskop, terdapat perbedaan fisik seperti bentuk, warna, aroma dan tekstur antara pakan lokal gabah) dan pakan import (oat). Namun jika hanya dilihat sekilas, oat dan gabah memiliki bentuk fisik yang sama.

\section{Bentuk}

Berdasarkan hasil pengamatan panelis untuk karakteristik bentuk gabah, $60 \%$ memilih bentuk ramping memanjang sedangkan karakteristik bentuk oat, 70\% panelis memilih bentuk gemuk memanjang. Hal ini sejalan dengan (Bowers, 2005) yang menyatakan bahwa bentuk gabah padi yang ada di Indonesia berbentuk tipis memanjang dan (Fast, 2000) menyatakan bahwa oat (avena sativa) memiliki bentuk bulat panjang. Berdasarkan hasil uji t, bentuk dari oat berbeda nyata $(\mathrm{P}<0,05)$ dengan gabah.

\section{Warna}

Berdasarkan hasil pengamatan panelis untuk karakteristik warna gabah, $90 \%$ memilih warna kuning kecoklatan sedangkan karakteristik warna oat, $60 \%$ panelis memilih warna kuning bersih.
Bowers, 2005 menyatakan bahwa warna padi atau gabah padi adalah berwarna kecoklatan, sedangkan oat memiliki warna kekuningan (Fast, 2000). Berdasarkan hasil uji t, warna dari oat berbeda nyata $(\mathrm{P}<0,05)$ dengan gabah.

\section{Aroma}

Berdasarkan hasil pengamatan panelis untuk karakteristik aroma gabah, $60 \%$ memilih aroma wangi (aroma khas gabah) sedangkan karakteristik aroma dari oat, $70 \%$ panelis memilih aroma wangi (aroma khas oat). Hal ini sejalan dengan (Bowers, 2005) yang menyatakan bahwa aroma yang dimiliki gabah padi adalah aroma yang memang aroma khas padi, sedangkan (Fast, 2000) menyatakan bahwa oat memiliki aroma khas oat. Jika oat menjadi tengik/busuk maka oat akan berbau tengik/busuk, lanjut Fast, 2000. Berdasarkan hasil uji t, aroma dari oat berbeda nyata $(\mathrm{P}<0,05)$ dengan gabah.

\section{Tekstur}

Berdasarkan hasil pengamatan panelis untuk karakteristik tekstur gabah, $70 \%$ memilih tekstur berambut, sedangkan karakteristik tekstur dari oat, $90 \%$ panelist memilih tekstur licin.

Bowers, 2005 menyatakan bahwa gabah padi memiliki terkstur yang cenderung kasar dan memiliki bulu atau 
rambut dan oat memiliki tekstur yang halus (Fast, 2000). Walaupun tekstur oat atau sekam oat halus, tidak boleh dimakan oleh manusia, tetapi hanya digunakan sebagai makanan hewan, terutama ternak ayam dan kuda Lanjut dikatakan Fast, 2000. Berdasarkan hasil uji t, tekstur dari gabah berbeda sangat nyata $(\mathrm{P}<0,05)$ dengan oat.

Karakteristik fisik yang sangat berbeda antara gabah dan oat terdapat pada tekstur, dimana gabah memiliki terkstur yang sangat berambut dibandingkan oat yang memiliki terkstur licin. Walaupun jumlah konsumsi gabah lebih tinggi dari oat, namun oat lebih efisien digunakan dibandingkan gabah (Tulung, 2012). Palatabilitas ternak pada oat lebih tinggi dibandingkan dengan gabah. Hal ini mungkin disebabkan karena (sifat fisik) dari gabah yang memiliki tekstur berambut.

\section{Uji Kimia Pakan Lokal dan Pakan Impor}

Data tabel 2 dan 3 menunjukkan nilai kandungan nutrisi dari pakan lokal dan pakan impor. Dari hasil uji t, menunjukkan bahwa kandungan nilai nutrisi pakan lokal berbeda nyata lebih tinggi $(\mathrm{P}<0,05)$ dibandingkan dengan pakan impor. Meskipun beberapa kandungan nilai nutrisi pakan impor lebih tinggi dari pakan lokal (tulung, 2012), menyatakan bahwa kuda pacu Minahasa yang mengkonsumsi pakan lokal dan kuda pacu Minahasa yang mengkonsumsi pakan impor mempunyai prestasi yang hampir sama saat dipacu. Secara kualitas dan kuantitas pakan impor memang jauh lebih unggul dibanding pakan lokal.

Tabel 2. Kandungan Nutrisi Bahan Pakan Lokal

\begin{tabular}{lccccccc}
\hline \multirow{2}{*}{$\begin{array}{c}\text { Jenis Pakan } \\
\text { Lokal }\end{array}$} & \begin{tabular}{c} 
BK \\
\cline { 2 - 8 }
\end{tabular} & $\begin{array}{c}\text { Energi } \\
(\mathbf{\% k a l )}\end{array}$ & $\begin{array}{c}\text { Protein } \\
(\boldsymbol{\%})\end{array}$ & $\begin{array}{c}\text { Lemak } \\
(\boldsymbol{\%})\end{array}$ & $\begin{array}{c}\text { SK } \\
(\boldsymbol{\%})\end{array}$ & $\begin{array}{c}\text { Ca } \\
(\boldsymbol{\%})\end{array}$ & $\begin{array}{c}\mathbf{P} \\
(\boldsymbol{\%})\end{array}$ \\
\hline Jagung & 87.9 & 3.67 & 10.4 & 4.1 & 2.5 & 0.1 & 2.56 \\
K. Hijau & 90.0 & 3.51 & 22.2 & 1.2 & 5.0 & 1.25 & 3.2 \\
Kedelai & 91.0 & 4.42 & 35.9 & 18.1 & 8.0 & 2.27 & 3.85 \\
Gabah & 86.8 & 3.52 & 8.4 & 1.8 & 9.7 & 0.12 & 2.9 \\
Rumput Lapang & 87.46 & 3.6 & 8.33 & 1.65 & 34.64 & 0.67 & 0.44 \\
Brachiaria Mutica & 88.42 & 3.5 & 10.41 & 1.98 & 32.09 & 0.77 & 0.53 \\
Tebon Jagung & 89.5 & 3.58 & 6.05 & 1.3 & 36.15 & 0.46 & 0.30 \\
\hline
\end{tabular}

Ket: Hasil Analisis Laboratorium Baristand Industri Manado (2014) 
Tabel 3. Kandungan Nutrisi Bahan Pakan Impor

\begin{tabular}{lccccccc}
\hline \multirow{2}{*}{$\begin{array}{c}\text { Jenis Pakan } \\
\text { Impor }\end{array}$} & BK & $\begin{array}{c}\text { Energi } \\
(\mathbf{M k a l})\end{array}$ & $\begin{array}{c}\text { Protein } \\
(\boldsymbol{\%})\end{array}$ & $\begin{array}{c}\text { Lemak } \\
(\boldsymbol{\%})\end{array}$ & $\begin{array}{c}\text { SK } \\
(\boldsymbol{\%})\end{array}$ & $\begin{array}{c}\text { Ca } \\
(\boldsymbol{\%})\end{array}$ & $\begin{array}{c}\text { P } \\
(\boldsymbol{\%})\end{array}$ \\
\hline Oats & 90.38 & 359.74 & 8.67 & 6.94 & 7.75 & 0.07 & 0.18 \\
Sustaina & 89.04 & 172.59 & 13.26 & 6.83 & 9.04 & 0.48 & 0.17 \\
\hline
\end{tabular}

Ket: Hasil Analisis Laboratorium Baristand Industri Manado (2014)

\section{Uji Kimia Kandungan Energi Pakan Lokal dan Pakan Impor}

Hasil analisis menunjukkan bahwa kandungan energi dari pakan impor berbeda sangat nyata dibandingkan dengan kandungan energi yang ada pada masingmasing pakan lokal. Berdasarkan hasil uji t, kandungan energi dari pakan lokal berbeda nyata lebih tinggi $(\mathrm{P}<0,05)$ dari pakan impor. Gibs et al. (2009) mengemukakan bahwa kuda pacu membutuhkan banyak energi untuk mencapai prestasi dan mempertahankan kondisi tubuh optimal saat mengikuti pelatihan dan perlombaan.

\section{Uji Kimia Kandungan Protein Pakan Lokal dan Pakan Impor}

Hasil analisis yang dilakukan, terdapat perbedaan kandungan protein antara pakan lokal dan pakan import. Berdasarkan hasil uji t, pakan lokal berbeda nyata lebih tinggi $(\mathrm{P}<0,05)$ dibandingkan dengan Pakan impor. (kacang hijau \& kedele) memiliki kandungan protein yang lebih tinggi dibandingkan dengan pakan import, namun kandungan protein dari jagung \& gabah padi lebih rendah dibanding pakan impor. Tulung, 2012 mengatakan bahwa nilai biologis pakan lokal lebih rendah dibandingkan dengan pakan impor sehingga, walaupun tinggi jumlah konsumsi protein, tetapi sedikit yang siap digunakan karena nilai biologisnya rendah. Para peneliti oat telah meneliti protein oat baik yang dihasilkan dengan teknik basah maupun kering, Sehingga oat sangat baik digunakan sebagai bahan pakan ternak (Peterson, 2004).

\section{Uji Kimia Kandungan $C a$ dan $P$ Pakan Lokal dan Pakan Import}

Hasil analisis menunjukkan adanya perbedaan kandungan nilai $\mathrm{Ca}$ yang dimiliki pakan lokal dan pakan import. Data hasil uji $\mathrm{t}$ menunjukkan bahwa kandungan nilai $\mathrm{Ca}$ pada pakan lokal berbeda nyata lebih tinggi $(\mathrm{P}<0,05)$ dibandingkan dengan pakan impor. Pakan lokal (kacang hijau \& kedele) memiliki kandungan $\mathrm{Ca}$ yang nyata lebih tinggi dibandingkan dengan kandungan $\mathrm{Ca}$ yang 
ada pada pakan import. Sedangkan kandungan $\mathrm{Ca}$ pada (jagung \& gabah padi) lebih rendah dibanding pakan impor.

Dari hasil uji t, menunjukkan bahwa kandungan (P) dari pakan impor berbeda nyata lebih tinggi $(\mathrm{P}<0,05)$ dibandingkan dengan kandungan $(\mathrm{P})$ pakan lokal.

Lawrence, 2004 mengemukakan bahwa keseimbangan kalsium dan fosfor sangat penting karena kalsium (Ca) dan fosfor (P) adalah mineral makro penting untuk pemeliharaan jaringan tulang, kontraksi otot dan metabolisme energi. Lanjut dikatakan bahwa rasio pemberian kalsium (Ca) dan fosfor (P) adalah 2:1, karena jika kandungan fosfor (P) lebih tinggi dari kalsium (Ca) akan mengakibatkan tulang melemah dan terjadi stres pada kuda.

\section{Uji Kimia Kandungan Bahan Kering Pakan Lokal dan Pakan Impor}

Hasil uji t, menunjukkan bahwa kandungan nilai Bahan Kering pakan lokal berbeda nyata lebih tinggi $(\mathrm{P}<0,05)$ dibandingkan dengan pakan impor. Pakan impor memiliki kandungan bahan kering yang lebih tinggi dibandingkan dengan kandungan bahan kering yang ada pada pakan lokal (jagung, gabah, hijauan. Sedangkan kandungan Bahan Kering pakan lokal (kacang hijau \& kedele) lebih tinggi dibandingkan kandungan Bahan Kering dari pakan impor (sustena).

\section{Uji Kimia Kandungan Serat Kasar Pakan Lokal dan Pakan Impor}

Hasil analisi menunjukkan adanya perbedaan kandungan nilai serat kasar yang dimiliki pakan lokal dan impor. Dari hasil uji t, menunjukkan bahwa kandungan serat kasar pakan impor berbeda nyata lebih tinggi $(\mathrm{P}<0,05)$ dibandingkan dengan pakan lokal. Pakan impor memiliki kandungan serat kasar yang nyata lebih tinggi dibandingkan dengan kandungan serat kasar yang ada pada pakan lokal (jagung \& kacang hijau). Namun kandungan serat kasar pada beberapa pakan lokal seperti kedele, gabah, hijauan lebih tinggi dibandingkan pakan impor.

Tulung 2012 mengemukakan bahwa untuk ternak kuda pacu, serat kasar yang tinggi dalam pakan bukan merupakan masalah karena kuda memiliki sistem pencernaan serat pada sekum dan kolon. Kohnke, 1992 mengemukakan bahwa kuda membutuhkan serat kasar yang cukup tinggi dalam pakan karena kuda memiliki sistem pencernaan fermentative dalam sekum dan kolon, namun NRC (1989) justru belum memberikan rekomendassi tentang kebutuhan serat kasar pada kuda.

\section{Uji Kimia Kandungan Lemak Pakan Lokal dan Pakan Impor}


Hasil analisis menunjukkan adanya perbedaan kandungan nilai Lemak yang ada pada pakan lokal dan pakan impor. Berdasarkan hasil uji t, kandungan nilai Lemak pakan lokal berbeda nyata lebih tinggi $(\mathrm{P}<0,05)$ dengan pakan impor. Kandungan nilai Lemak pakan lokal (kedelai) jauh lebih tinggi dibandingkan dengan pakan impor. Namun kandungan Lemak pada pakan impor jauh lebih tinggi dibandingkan dengan pakan lokal (jagung, kacang hijau, gabah, hijauan).

Untuk kebutuhan ternak, konsentrasi lemak yang tinggi sangat baik karena sebagai sumber energi daripada karbohidrat (Fast, 2000). Penetuan lemak sama dengan serat kasar dan belum ada yang baku untuk kuda (NRC, 1989).

\section{KESIMPULAN}

Berdasarkan hasil penelitian dapat ditarik kesimpulan bahwa karakteristik fisik dan kimia pakan impor lebih baik dari pakan lokan

\section{SARAN}

Perlu adanya sentuhan teknologi, agar pakan lokal dapat digunakan sebagai pakan utama ternak kuda pacu Indonesia.

\section{DAFTAR PUSTAKA}

Bowers, K. K. 2005. Everything Oats. http://www.karenskitchen.com/ a/recipe oat.htm. Diakses tanggal 8 Januari 2015.

Blakely, J dan D. H Bade. 1992. Ilmu Peternakan. Penerjemah B. Srigdanono. Gadjah Mada University Press. Yogyakarta.

Fast, R. B. and Elwood, F. 2000. Breakfast Cereals and How They are Made $2^{\text {nd }} E d$. Caldwell, The American association of cereal chemistry Inc. USA.

Gibs, P. G. dan G. D. Potter. 2002. Concepts in Protein Digestion and Amino Acid Requirements of Young Horses. Professional Animal Scientist.

Gibs, P. G. dan G. D. Potter. Dan B. D. Scott. 2009. Feeding Race Prospects and Racehorses in Training. Texas A\&M University Department Of Animal Science Equine Science Program. Edited by Michael Benefield. Edited by Michael Benefield. 
McEllhlary, R. R. 1994. Feed Manufacuring Technology IV. Am. Feed Industry Assoc. Inc. Aruington

Oroh, R.K.P. 2004. Determinasi Kebutuhan Energi Untuk Kerja Berdasarkan Jumlah Pakan Yang Dikonsumsi Dalam Bahan Kering, Bobot Metabolik, dan Beban Kerja Kuda Pacu. Skripsi. Jurusan Ilmu Nutrisi dan Makanan Ternak. Fakultas Peternakan - Unsrat. Manado.

Peterson, D. M. 2004. Oat-a Multifunctional Grain. Proceedings $7^{\text {th }}$ International Oat Conference. http://www.mtt.fi/met/pdf/met51.pdf . Diakses tanggal 8 Januari 2015.

Tulung, Y.L.R. 2011. Kebutuhan Energi dan Protein Kuda Pacu Indonesia dan Aplikasi Pada Formulasi Ransum Bahan Pakan Lokal. Disertasi. Program Pascasarjana, IPB. Bogor.

Lawrence, L. A. 2004. Feeding The Performance Horse. Washingston State University Extension. Subject Code 160. A 